\title{
The Analysis of the Development and the Application of Islamic International Relations Methodology in the University of Darussalam Gontor
}

\author{
Rudi Candra ${ }^{1, *}$ Sofi Mubarok ${ }^{2}$ \\ ${ }^{1}$ Dept. International Relations, University of Darussalam (UNIDA) Gontor, Ponorogo, Indonesia \\ ${ }^{2}$ Dept. International Relations, University of Darussalam (UNIDA) Gontor, Ponorogo, Indonesia \\ *Email: rudicandra@unida.gontor.ac.id
}

\begin{abstract}
This research is the advancement of research entitled "Analysis of the development of Islamic Perspectives in International Relations in Indonesia" which found that one of the problems of scientific publications lack related to Islamic International Relations in Indonesia is relevant to the methodology of the Islamization of International Relations. This condition reminds us of the vital role and urgency of developing Islamic International Relations methodology. In response to this, it is necessary to analyze the development and applying the methods of Islamic International Relations in Higher Education in Indonesia, in this case, the University of Darussalam Gontor (UNIDA Gontor). UNIDA Gontor was chosen because it has officially declared itself as the centre of the Islamization of knowledge in Indonesia. This study aims to analyze the development of the methodology of Islamic International Relations at UNIDA Gontor to then be compared and evaluated for its application in several other tertiary institutions in Indonesia. This type of research uses descriptive qualitative by taking a research location in the Darussalam University of Gontor Ponorogo. Data collection techniques through observation, interviews and limited discussion. The data analysis through an interactive model with a four-component analysis approach, namely: data reduction, data analysis, data clarification and drawing conclusions, which are carried out in an active, interactive form with resource persons as primary data sources supplemented by several secondary sources. This research found that UNIDA Gontor in developing the methodology of Islamic International Relations used several existing methodological approaches to the Islamization of knowledge and developed Islamization methods model independently for university-level and several branches of knowledge, in this case specifically the International Relations.
\end{abstract}

\section{Keywords: Islamization, International Relations, Methodology, UNIDA Gontor}

\section{INTRODUCTION}

The body text starts with a standard first-level heading like INTRODUCTION or any other heading suitable to the content and context. First level headings are in all caps. Copy the content and replace it for other first-level headings in remaining text. Reference citations should be within square bracket [1]. Headings should always be followed by text.

The Islamization of International Relations is one of the most developed studies today, especially in Indonesia. Furthermore the spread of concepts of Islamization, it even reduced the idea of Islamic liberalization in the early 2000s. The strength of the spread lies in its roots, which were embedded in several
Islamic campuses in Indonesia, and then became a popular study among Muslim academics in Indonesia. Needless to say, this influence has also reached groups of international relations academics by developing curricula or study groups as an effort to develop a systemic discourse on Islamization.

The idea of the Islamization was initiated for the first time during a world conference on Muslim education in Mecca in 1977. This conference was initiated by the King Abdul Aziz University of Saudi Arabia. In the forum, the idea of the Islamization emerged, expressed by the two main initiators of this movement, namely Ismail Raji Al-Faruqi and Muhammad Naquib Al-Attas. According Al-Faruqi, the Islamic education system was formed within the 
framework of Western core characterized by value-free, especially divine spiritual values. Meanwhile, based on Al-Attas' argument, the biggest challenge faced by Muslims today is the onslaught of knowledge from Western civilization that has been spread throughout the world.

According to Al-Attas, what the things were initially carried out in the Islamization was the liberation of humans from magical, mythological, animistic, national-cultural traditions, and then from the secular understanding of their thoughts and language. [2] In other words, the process of purifying the soul before it is decorated with commendable qualities. In the process, two steps are suggested: first, to isolate the elements and concepts formed by Western culture and civilization, second, to incorporate key Islamic elements and concepts into every relevant branch of contemporary science. [3] [4]

Different from Al-Attas, who started the process of Islamization with Al-Ghazali's self-purification (Sufism), Al-Faruqi offered twelve steps that must be followed in the process of Islamizing knowledge. The 12 steps are 1 . The understanding of modern disciplinesmethodological principles, problems, themes, and, their development 2. Review of disciplines 3. The understanding of Islamic values (anthology) 4. The understanding of Islamic heritage (analysis) 5. The determination of distinct Islamic relevance to contemporary issues. 6. A critical assessment of modern disciplines-clarifying the position of the discipline from Islam and guiding the steps 7 . A critical assessment of the Islamic heritage-understanding such as the Al-Quran and Sunnah 8. The main subject of the discourse is Islamic issues 9. The subject of the discourse is human problems 10. Analysis and creative synthesis 11 . Referring to disciplines within the framework of Islam: university textbooks, and 12. Dissemination of Islamic knowledge. [6] [12]

In International Relations, the discourse of Islamization has also begun to show its stretch. In a book entitled "Methodology of International Relations in the Debate of Paradigmatics and Alternative Approaches" by Alexander Wendt, et.al, it is explained that the Islamic methodology can be used as a solution, at least one of the articles entitled "Tradition of Islamic International Relations Methodology: Arkoun's Alternative to Epistemological Crisis. Western / Modern International Relations written by Musa Maliki. In the article, it is explained that Arkoun, as one of the Islamic thinkers, believes that Islam and the study of International Relations have a constitutive relationship, namely relationships that form, present, and convince IR scholars that understanding the history of international structures is the result of the collaboration between the two. Arkoun believed that Islam and the West, especially Europe, were integral, but it was interrupted by a dark historical moment, for instance, the claim that European historians mentioned European authenticity was when they faced Islam at the moment of the Crusades. The moment which makes the difference is binary or competitive opposition therefore, the existence of Europe is present in real terms, both geographically and existentially with the consequence of negating Islam. And the idea of the East and West have clashed should not exist because they both have complementary relationships and build a common civilization formation. [13]

Another book that discusses the study methodology of International Relations in an Islamic perspective is "Non-Western International Relations Theory Perspectives on and beyond Asia" written by Amitav Acharya \& Barry Buzan, specifically written in an article entitled "International relations theory. and the Islamic worldview "by Shahrbanou Tadjbakhsh, explained in the article that the uniqueness of Islamic IR study lies in the references used, namely the three main sources of law in Islam itself, namely: the holy book of the Qur'an, the Sunnah of the Prophet which is sourced from The traditions of the Prophet Muhammad, and the results of the Ijtihad of the scholars. [1] Because it is sourced from religious texts, the methodology used emphasizes the faith approach as the main foundation for later development in scientific narratives, unlike from the Western approach which does not believe in metaphysical realities in scientific development.

the latest discussion of Islamization of international relations in Indonesia can be observed in a research article entitled "Islamic International Relations as a Potential Tool to Indonesia's Soft Power Diplomacy", research written by Sofi Mubarok \& Rudi Candra and published by the international publication Atlantis Press In 2020, it explained that countries with Muslim majority populations nowadays are in economic and security dilemmas, such as Sudan, Egypt, Iraq, Libya, and several other Muslim countries. That is clear evidence of how the democratic diplomacy process developed by the West did not work or incompatible with the climate and culture that developed in Islamic countries. This research presents an alternative offer in the form of theoretical development of Islamic International Relations as a solution to this failure. [10]

However, the offer to develop the Islamic International Relations has not yet reached the expected target, this can be detected from the lack of scientific publications with the theme of Islamic International Relations, whether sourced from Islamic universities or the results of independent research conducted by researchers and interested in Islamic IR. The research report published in the Jisiera journal at the end of 2019 with the title Islamic "Perspective In International Relations An Analysis of Its Development in Indonesia" gave a crystal-clear idea of the low results of research 
with a background in Islamic International Relations are due to the weak development of the Islamic methodology itself. It happened because most of the universities did not have a methodological format that was suitable and could be developed within the educational institution. [11]

Therefore, the main object of this research is to observe how the development of Islamic International Relations methodology in Islamic campuses in Indonesia, especially at the University of Darussalam Gontor, which since its inception has made the Islamization became the main feature of the university.

\section{METHODOLOGY}

This research methodology uses qualitative approach. The research aimed to analyze various information from data that has been obtained from the sources which are primary or secondary. The data explanation followed by the research object analysis. The data is collected from the publication of scientific journals that are online and offline, documents of the universities, and from the interview process with the authoritative person in University of Darussalam Gontor. After being verified, analyzing data were taken, then it describe as reality and fact.

\section{RESULT AND DISCUSSION}

The strategy and methodology of the Islamization of knowledge are very much influenced by the thought or school of Islamization of knowledge itself. In its application in higher education, for example, the stages that must be taken have consequences and intellectual responsibilities of its own. Therefore, an institution that wants to develop the Islamization of knowledge, from the start, must be finished with the academic debate that occurs. This is also what UNIDA Gontor did in developing the project of Islamization of the science of international relations.

The debate about the Islamization of knowledge is still an exciting issue lately. Not only disputes about whether or not to agree with the idea of Islamization of knowledge have clear boundaries, but debates also occur between proponents and initiators of the Islamization of knowledge itself. This debate formed the two primary schools of thought in the Islamization of knowledge, represented by two thinkers and founders of the Islamization of knowledge, Syed Naquib Al-Attas and Ismail Raji Al-Faruqi. In principle, these two thinkers have several similarities, as there have been previous explanations. However, they also have quite fundamental differences.

This difference will undoubtedly affect the strategy and methodology chosen by a higher education institution in developing the Islamization of knowledge.
UNIDA Gontor, although it has autonomous interpretations of the Islamization of knowledge, the influence of Al-Attas appears to be dominant in the application of its Islamization. Although, other views have also become a discourse for discussion in the development of the Islamization of this science.

According to Al-Attas, Islamization started from the tazkiyatun nafs or cleansing the subject's soul. By cleansing the soul and decorating it with praiseworthy qualities, so that in the process of Islamizing knowledge, an excellent human person will automatically be formed and become Islam well. [2] According to Al-Attas, that Islam is perfect and includes all that is needed by humans, Islam for him is both religion and civilization. Therefore, the object of Islamization, according to Al-Attas, only includes contemporary sciences which have been infiltrated by secularism.

Therefore, the work program for the Islamization of knowledge according to Al-Attas includes two steps;

1. Isolating the key elements and concepts that make up Western culture and civilization, these elements include:

a. Intellect as a guide for human life

b. Be dualistic towards reality and truth

c. Affirming aspects of existence that project a secular view of life

d. Defending the doctrine of humanism

e. Making drama and tragedy as dominant elements in the nature and fact of humanity

2. Incorporating Islamic aspects along with essential concepts in each relevant field of current science, the main ideas of Islam in question are:

a. Religious concept (din)

b. The concept of Human (insan)

c. The concept of knowledge ('ilm and ma'rifah)

d. The concept of wisdom (wisdom)

e. The concept of justice ('adl)

f. The concept of right action ('amal as adab)

g. The concept of universality (kulliyah jami'ah)

From this framework of thinking, the Islamization process at UNIDA Gontor more practically implements three main approaches, namely tazkiyatun nafs or Islamization of the worldview, mastering the science of international relations and Islam, and integration that ends with Islamization.

First, as an implementation of tazkiyatun nafs, the International Relations Study program, following 
UNIDA Gontor, since its inception, it has made the Islamization of knowledge a vision of the study program. The purpose of tazkiyatun nafs is the Islamization of the worldview or mindset and perspective. Of course, the Islamization in question is the Islamization of contemporary science as expressed by Al-Attas. In the university of Darussalam prospectus 2020, it is attached that the vision of the UNIDA Gontor International Relations study program is "Become the leading study program in 2025 that produces competitive undergraduate in the field of international relations oriented towards the Islamization of Contemporary Science in the boarding school system." [9]

This vision is applied in an orderly manner in four missions, namely:

1. Organizing the education and teaching process in Islamic world studies by integrating International Relations and Islamic Sciences.

2. Developing research in the Science of International Relations, especially the course of the Islamic World, which is integrated with Islamic Science.

3. Organizing community service to apply knowledge, skills and research results in response to the dynamics of international relations.

4. Expanding the network of cooperation to support the development of the integration of International Relations and Islamic Sciences.

In the vision and mission, it can be seen that from the start the science of international relations at UNIDA Gontor was indeed built on this foundation. Although the use of the word 'integration of science' is debatable because the term tends to lead to the Islamization methodology, according to Al-Faruqi. However, as previously explained, even though UNIDA Gontor is more inclined towards Al-Attas, it has also conducted practical trials of the Islamization methodology with several other approaches.

In carrying out the program of Islamization of the science of international relations, in addition to carrying out the same vision and mission that leads to the Islamization of knowledge, UNIDA Gontor also initiated the formation of an Islamization directorate of islamization science. This directorate directly collaborates with the study program in compiling its Islamization program in the academic area. This directorate prepares programs as well as a special Islamization curriculum which is integrated with the study program curriculum. So each study program at UNIDA Gontor is required to include nine Islamization courses, with teachers from the directorate.
In addition, the directorate of islamization science occasionally holds intensive discussions with lecturers who are experts in various disciplines and those who are competent in various fields of Islamic studies such as theology, philosophy, tafsir (tafsir), the prophetic tradition (hadith) and Islam. Jurisprudence. This series of discussions is the steps for curriculum design and evaluation of its implementation. In the early stages, the discussion focused on elaborating basic Islamic concepts that are relevant and needed by various disciplines. The next stage of the discussion is refined with the concept of science and epistemology and is continued with the history of science in Islam related to their respective majors. Finally, the discussion is directed at student problems in facing the process of integration of contemporary Islamic and Western sciences.

Apart from the academic program, UNIDA Gontor also strengthens kepesantrenan education which is integrated with study programs and faculties with the establishment of the directorate of guidance and counceling. The directorate of guidance and counceling is an institution that assists the rector and vice-rector I in fostering santri students outside of class hours.

This directorate oversees all kepesantrenan programs that are integrated with study programs, the directorate of islamization science, and other institutions under the umbrella of UNIDA Gontor [9] This nurturing program, like the study program's academic curriculum, also has grades that are recapitulated every semester. This pesantren value is a pass requirement for all UNIDA Gontor students. Assessment of kepesantrenan includes several categories such as science, spirituality, arts and sports, organization, service, and experience and academic support. These six categories are broken down into several activities that can be followed by students.

In addition, the Al-Qur'an memorization program is also one of the tazkiyatun nafs programs in the context of the Islamization of knowledge at UNIDA Gontor, in this case, the Islamization of the science of international relations. Every student is required to memorize one juz every two semesters. So in total, every student who passes must have learned at least four juz Al-Qur'an. This memorization program is included in the academic curriculum.

The second approach taken in the Islamization of international relations is by mastering Western international relations and Islamic sciences. This mastering process takes two paths; first, the application of two different studies, namely the science of international relations and Islamic sciences in the curriculum and the second is strengthening the understanding of Islamic sciences through a weekly study program for lecturers. These two programs go hand in hand and always develop along with the development of the Islamization process itself. 
The first process is mastering international relations and Islamic sciences in the curriculum. In this process, courses based on the sciences of international relations are taught concurrently with several Islamization courses.

Meanwhile, if we take a look at the Islamic University of Indonesia (UII), from the sixty-one graduates, only four theses wrote about IR in Islamic perspectives. It means that only $6.56 \%$ of the students' thesis titles use the Islamic approach in their thesis

Table 1. The distribution of courses in international relations study program [5]

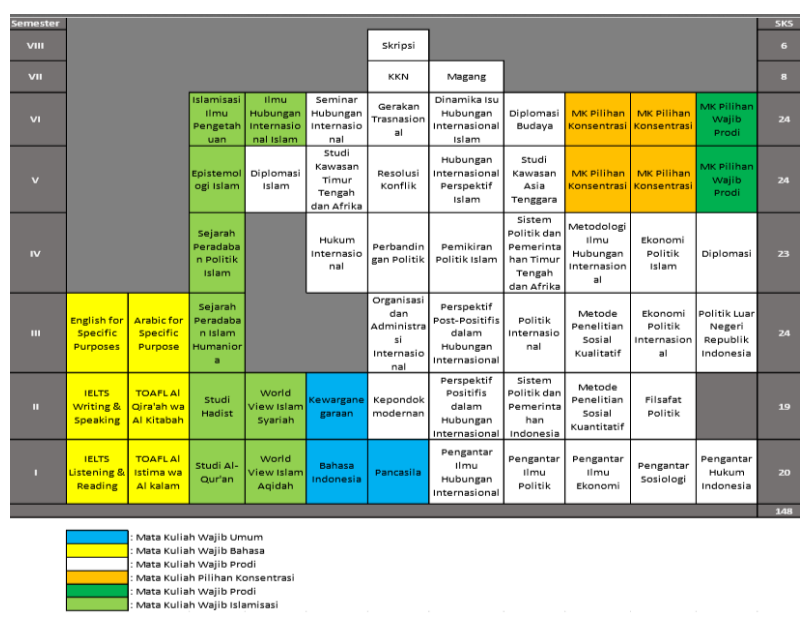

In the table above, it can be seen that Islamization courses are taught in conjunction with available general courses. This course, as previously explained, is a compulsory subject from the Directorate of islamization science of UNIDA Gontor. In detail, the nine Islamization subjects can be defined as follows:

World View Islam Aqidah 1. Worldview Islam I is the core curriculum and core competencies for all study programs at UNIDA Gontor. This course is designed to form students' aqidah fikriyah by equipping them with the correct frame of mind and perspective in seeing all the realities of existence based on critical concepts in Islamic teachings. After attending this lecture, students can (1) understand the meaning of the worldview and its influence in shaping a person's mindset, attitudes, and behaviour, (2) explain key concepts in Islam which include the concepts of religion, god, revelation, Prophet, af'al al-ibad (human), nature, and eschatology as well as the comparison of Islam with other religions.

World View Islamic Sharia. As a continuation of the Islamic Worldview 1, this course is intended to equip students with views on Islam as sharia and morals that shape the system of worship, ethics and law. After attending this lecture, students are able to explain (1) the meaning of sharia and the concept of tasyri ', (2) the concept of worship, morals, and the relationship of worship to morals, (3) the concept of law and maqashid sharia, and (4) the Islamic view of human rights.
Study of the Al-Quran. This course provides an explanation of three main points of discussion: 1 . About the history of the Koran, which includes: the Koran and Revelation, Asbab al-Nuzul, Codification of the Koran, 2. About the Koran as a Source Knowledge: which includes a discussion of the Koran and Natural Sciences, humans and the value of life, the Koran and I'jaz alIlmiy. 3. Regarding general principles in the interpretation of the Koran, as well as the Development of Tafsir (Classical, Middle and Contemporary), as well as how it should interact with the Koran.

Hadith Studies. This Hadith Study course is intended to provide students with insights, worldviews of science by using the perspective of hadith science, and to emphasize that hadiths take an essential part as a source of knowledge and civilization. The material presented includes the definition of Hadith, Hadith during the time of the Prophet Muhammad, the companions, and the codification era, the position and function of hadith as a source of Islamic teachings, Orientalism and the study of hadith, Understanding the science of hadith, the history of development and its branches, Hadith and Science (i'jaz al-Ilmy), Hadith Criticism, Actualization of Hadith, Inkar al-Sunnah and Living Sunnah: methods of understanding the living sunnah.

History of Islamic Civilization Humanities. The Humanities Islamic Civilization course equips students with three main things: 1 . About intellectual traditions in Islam, 2. History of Science in Islam, 3. History of the birth of the Humanities: Sharia Sciences, Islamic Politics, Islamic Economics, Islamic Psychology, Communication Islam, History and Management of Islam, History of Education, History of Art and Music.

Islamic Epistemology. This course (Philosophy of Science in Islam) will study and explore, four subject matters: 1. Meaning and concept of Science in Islam, 2. Classification and Hierarchy of knowledge in Islam, 3. Sources of knowledge in Islam, 4. The object of Science in Islam, 5. Islamic scientific paradigm and 6 . Knowledge and Morals.

Islamic International Relations. This course explains the interpretation of the Holy Qur'anic verses related to the discipline of International Relations, ranging from aspects of security, economy, cooperation, diplomacy, ethics in the war to human attitudes towards the environment. One of the uniqueness of Islamic International Relations is the primary source of reference, namely the Holy Qur'an, which is understood and studied by reading, researching and analyzing interpretations of the Qur'an written by commentators, for then developed by reading and researching observations of hadiths and the history of the Prophet Muhammad and his companions. In the continued process of this course, every student who takes the Islamic International Relations Course is required to 
memorize the verses of the Al-Qur'an and the Prophet's Hadith that he has learned. [5]

The second process is strengthening the mastery of Islamic sciences or the Islamization of knowledge material for lecturers. This process is the teaching of Islamization materials to lecturers by the Islamization team every two weeks. Islamization material taught to lecturers is not much different from what is taught in the Islamization curriculum for students. [9]

Different from students who require mastering two different studies, for lecturers, because academically they are considered capable in the field of international relations, the emphasis lies in increasing their understanding of Islamic sciences and Islamization. In addition to the bi-weekly agenda, several times a workshop on the Islamization of knowledge was held for lecturers with competent resource persons.

Third, an integration which means isolating Western concepts and incorporating Islamic elements. This process led to the Islamization of the science of international relations. This process is carried out in three forms; first, the preparation of integrated courses; second, the publication of research results from lecturers and students; third, mentoring and weekly discussion of student Islamization.

The first form is to compile gradually, courses that have been able to be integrated, namely Islamic political thought, Islamic diplomacy, and international relations in an Islamic perspective. These three courses are the first results of the Islamization process of the science of international relations. Even so, the three subjects are always evaluated in terms of methodology and quality.

The second bet is the publication of research results from lecturers and students related to the Islamization of international relations. As a means of publication, UNIDA Gontor in collaboration with the International Relations study program, UNIDA Gontor, initiated two journals that carry the main theme of the Islamization of the science of international relations. The first is the dauliyah journal, which is a study program journal that has now been accredited by SINTA 4 . The second is the mediation journal, which is actually intended more specifically for students as a means of publishing the results of their research. In addition to publication in the form of journals, the process of Islamizing the science of international relations at UNIDA Gontor is also carried out by publishing books on the theme of Islamization of the science of international relations. The publishing process is still in the process of editing and review by several experts in international relations and Islamic studies in Indonesia and abroad.

The third form of this process is that the directorate of islamization science facilitates students to develop their analysis regarding the integration of Islamic sciences and international relations which they have learned in class through mentoring and regular weekly discussions. Mentoring is a weekly routine study program as a means of deepening and enriching Islamization material. Mentoring is specifically for students in the 1-4 semester who are taught by 7 thsemester students under the guidance of a lecturer who teaches Islamization through routine meetings every two weeks. Meanwhile, the discussion is a weekly routine study program designed for students in semesters 5-6 to build awareness about the process of integration of knowledge by bringing together students from general study programs and Islamic studies. This discussion, in the process of Islamizing the science of international relations at UNIDA Gontor, is expected to hone students in analyzing international relations issues using the Islamic worldview. [9]

The three processes above are continuous efforts carried out by UNIDA Gontor to carry out Islamization, especially the science of international relations. This endeavour certainly has several obstacles and challenges. Apart from the fact that Islamization is a relatively new approach, especially for academics of international relations, there is also a lack of accessible publications related to the Islamization of international relations.

According to the head of the UNIDA Gontor International Relations study program, Fadhlan Nur Hakiem, the process of Islamization of the science of international relations at UNIDA Gontor has since been rolled out like a place. [7] This means that even though several approaches have been taken, the results of this process, such as theses and other publications that implement Islamization are still far from expectations. The biggest challenge is that the lecturers' understanding of the concepts of Islamization has not yet reached the internalization stage. Even though the material on Islamization has been and is still being implemented every two weeks for all lecturers, it has not had much impact on the lecturers' understanding of Islamization, in this case about the application of Islamization in the science of international relations.

However, the efforts in the International Relations study program itself continue to be improved to make this Islamization program a success. For example, in the 2020 curriculum evaluation, several courses that are less related to the science of international relations such as export-import courses are replaced with political studies and regions of the Islamic world which are contained in two subjects, namely the political system and governance of the Middle East and Africa and Middle East regional studies. And Africa. This, according to Hakiem, is because the two regions reflect the Islamic world region and the frequent issues concerning the Islamic world develop from that region. In general, although the road appears to be in place, it is pointing in the right direction, continued Hakiem. [7] 
In line with Hakiem, according to the person in charge of Islamization of international relations from the team of the directorate of islamization science, Fardana Khirzul Haq, stated that the main challenge of Islamization of the science of international relations is the lack of joint work between Islamization lecturers and international relations lecturers. [8] That way, the works of Islamization lecturers are more inclined to discuss political jurisprudence which is practically closer to the law than to the area of International Relations, while the lecturers of international relations publish more about the study of international relations which has no Islamization element. In addition, there is still a lack of a writing tradition among students and a very strong tradition of speaking, making the results of discussions that may have Islamic content in the science of international relations cannot be published.

\section{CONLUSION}

The Islamic methodology of international relations at UNIDA Gontor is in its 6th year, meaning academically and scientifically, six years is a very short time. However, technically speaking, the process of Islamization of international relations at UNIDA Gontor has shown a clear and directed pattern. Although of course, from some of the existing developments, there are still gaps and notes that need to be fixed.

In general, the Islamization of the science of international relations at UNIDA Gontor was built independently. Although many programs were influenced by Al-Attas' views, in the mastering program, for example, the nuances of Al-Faruqi were very little felt. That is, the methodology of Islamization of the science of international relations at UNIDA Gontor is the result of reflection on the thoughts of the initiators of Islamization, in addition to implementing evaluation and development in the academic world of higher education.

In its journey, the Islamization of the science of international relations at UNIDA Gontor has gone through three stages. First, tazkiyatun nafs in the AlAttas language or in the language of UNIDA Gontor the Islamization of the worldview which begins with the Islamization of knowledge and ends with the Islamization of behaviour (adab), institutions and products. [9] In its implementation is reflected in the vision and mission of the international relations study program which is in line with the vision and mission of UNIDA Gontor regarding Islamization. Besides, the implementation of tazkiyatn nafs is also reflected in the overall supervision of the students' lives outside of academic hours the directorate of guidance and counceling which is also considered to be equivalent to the achievement of academic scores.
Second, mastering the science of international relations based on a secular Western perspective and Islamic sciences. The mastering process takes two forms; the first is the mastering process which is manifested in a curriculum containing Islamization as well as international relations courses. Second, mastering Islamization material for lecturers. This process is carried out regularly by the Islamization team every two weeks in the form of a series of studies on Islamic materials.

Meanwhile, the last process is integration, which means isolating Western concepts and incorporating Islamic elements. This process led to the total Islamization of the science of international relations. The implementation of this process goes through three stages, namely related to integrated course design, publication, as well as mentoring and discussion.

Of these three processes, the process of Islamizing the science of international relations at UNIDA Gontor is of course still far from being desired. In the future, of course, there is still a need for comparative research on the methodology of Islamization that is applied in other institutions so that this study of Islamization becomes developed.

\section{REFERENCES}

[1] Acharya, A. a. (2010). Why Is There no NonWestern International Relations Theory? An Introduction. In A. a. Acharya, Non-Western International Relations Theory: Perspectives on and beyond Asia. Routledge.

[2] Al-Attas, S. M. (1995). Prolegomena to The Metaphysics of Islam. Kuala Lumpur: ISTAC.

[3] Armayanto, H. (2007, September). Relevansi Islamisasi Ilmu Pengetahuan Kontemporer. Jurnal Studi Agama-Agama dan Pemikiran Islam, 15-33.

[4] Daud, W. M. (1998). The Educational Philosophy and Practice of Sayyed Muhammad Naquib al-Attas - An Exposition of the Original Concept of Islamization. Kuala Lumpur: ISTAC.

[5] Draft Dokumen Kurikulum Berbasis Outcme Based Education (OBE) tahun 2020-2024. (2020). Ponorogo: Program Studi Hubungan Internasional .

[6] Faruqi, I. R. (1995). Tauhid. Bandung: Pustaka.

[7] Hakiem, F. N. (2020, 8 25). Islamization of International Relations in UNIDA Gontor. (R. Candra, \& S. Mubarok, Interviewers)

[8] Haq, F. K. (2020, 8 26). Islamization of International Relations in UNIDA Gontor. (R. Candra, \& S. Mubarok, Interviewers) 
[9] M. Syahrul Syarifuddin, S. (2020). Panduan Universitas; Universitas Darussalam Gontor 1440/1441 /2020/2021. Ponorogo: UNIDA Gontor Press.

[10] Mubarok, S., \& Candra, R. (2020). Islamic International Relations as a Potential Tool to Indonesia's Soft Power Diplomacy. 1st Borobudur International Symposium on Humanities, Economics and Social Sciences (BIS-HESS 2019) (pp. 954-959). Atlantis Press.

[11] Mubarok, S., \& Chandra, R. (2019, 8 20). Islamic Perspective in International Relations. The Journal of Islamic Studies and International Relations, 4(1), 1-16.

[12] Soleh, A. K. (2011). Mencermati konsep Islamisasi ilmu Ismail R Faruqi. Ulul Albab, 1-21.

[13] Wendt, A. (2014). Metodologi ilmu hubungan internasional: perdebatan paradigmatik dan pendekatan alternatif. In J. S. Alexander Wendt. Malang: Intrans Publishing. 